\title{
THE IMPACT OF COOPERATIVE LEARNING TYPE MAKE A MATCH TEACHING MODEL TOWARD UNDERSTANDING SAINS CONCEPT IN THE REVIEW OF LEARNING MOTIVATION IN ELEMENTARY SCHOOL
}

\author{
Istabiqul IIma, Kartono, Anesa Surya \\ Universitas Sebelas Maret \\ ilmaistabiqul@gmail.com
}

Article History

accepted 09/07/2018

approved 01/08/2018

published 17/09/2018

\section{Keywords}

make a match, explicit instruction, learning motivation, understanding sains concept

\begin{abstract}
The low of understanding sains concept and learning motivation caused by implementation of the teaching model that not appropiete. One of the learning model that impact to understanding sains concept and learning motivation was cooperative learning type make a match. The purposes of the research are to know (1)the difference of understanding sains concept between students that teached by cooperative learning type make a match model and students that teached by explicit instruction model; (2) the difference of understanding sains concept between students that had high learning motivation and students that had low learning motivation. The research was used Quasi Eksperimental method with $2 \times 2$ factorial design. This research used Two Ways Anava data analysis. The conclution were (1) there was the difference of understanding sains concept between students that teached by cooperative learning type make a match model and students that teached by explicit instruction model; (2) there was the difference of understanding sains concept between students that had high learning motivation and students that had low learning motivation.
\end{abstract}

Social, Humanities, and Education Studies (SHEs): Conference Series

p-ISSN 2620-9284 https://jurnal.uns.ac.id/shes e-ISSN 2620-9292 


\section{PENDAHULUAN}

IImu Pengetahuan Alam (IPA) perlu dipelajari karena berhubungan dengan kehidupan manusia sehari-hari. IPA merupakan rumpun ilmu yang memiliki karakteristik khusus dalam mempelajari fenomena alam yang faktual (factual), baik berupa kenyataan (reality) atau kejadian (event) dan hubungan sebab-akibatnya (Wisudawati dan Sulistyowati, 2014). Pembelajaran IPA di Sekolah Dasar menekankan pada bagaimana mengembangkan rasa ingin tahu dan daya berpikir kritis peserta didik terhadap suatu masalah.. Susanto (2013) menyatakan para guru belum sepenuhnya melaksanakan pembelajaran secara aktif dan kreatif dalam melibatkan siswa serta belum menggunakan berbagai pendekatan/strategi pembelajaran yang bervariasi berdasarkan karakter materi pelajaran. Desain pembelajaran yang tepat dapat mempengaruhi pemahaman konsep dan motivasi belajar siswa menjadi lebih baik.

Guru melakukan proses pembelajaran dengan bertanya kepada peserta didik tentang materi pembelajaran yang dipelajari, salah satu peserta didik menjawab sedangkan peserta didik lain cenderung pasif. Penerapan model pembelajaran yang dilakukan oleh guru juga belum mengarah ke pembelajaran yang membentuk siswa ke dalam kelompok-kelompok kecil sehingga sifatnya siswa masih menerima informasi langsung dari guru bukan mencari informasi. Proses pembelajaran yang dilaksanakan di SD tersebut sesuai dengan model pembelajaran explicit instruction. Model pembelajaran explicit instruction adalah suatu strategi yang dapat digunakan oleh guru untuk menyampaikan pelajaran yang diinformasikan langsung kepada siswa (Huda, 2014: 186). Strategi ini dapat berbentuk ceramah, demonstrasi, dan pelatihan atau praktik. Selama proses pembelajaran, siswa tidak dihadapkan langsung pada contoh melainkan siswa hanya diberi arahan untuk membayangkan benda yang dimaksud oleh guru. Banyak siswa yang belum menguasai materi yang disampaikan guru, hal tersebut dapat diamati dari kurangnya penguasaan siswa dalam membuat contoh yang berhubungan dengan kehidupan sehari-hari.

Rendahnya penguasaan oleh siswa dapat dipengaruhi oleh beberapa faktor, salah satunya adalah disebabkan oleh rendahnya motivasi belajar siswa. Penelitian mengenai rendahnya motivasi belajar siswa dapat dilihat dari penelitian oleh Santoso (2013). Berdasarkan hasil perhitungan, diketahui pengaruh motivasi belajar siswa terhadap hasil belajar fisika adalah $51,9 \%$ dan sisanya dipengaruhi oleh faktor yang lain. Berdasarkan hasil penelitian tersebut membuktikan bahwa penerapan metode pembelajaran yang sesuai dapat mempengaruhi motivasi belajar siswa secara signifikan.

Salah satu cara yang dapat diterapkan untuk menarik perhatian siswa adalah dengan menggunakan model pembelajaran yang sesuai dengan perkembangan siswa dan materi pembelajaran. Menurut Trianto (2013) pemilihan model pembelajaran sangat dipengaruhi oleh sifat dari materi yang akan diajarkan, tujuan yang akan dicapai dalam pembelajaran tersebut, serta tingkat kemampuan peserta didik. Model pembelajaran yang mengajak siswa untuk aktif dan berpikir kritis serta menyenangkan bagi siswa sehingga siswa mampu mengikuti pembelajaran secara maksimal. Model pembelajaran tersebut terdapat dalam model pembelajaran kooperatif. Model pembelajaran kooperatif mengacu pada kerjasama yang terjalin antar siswa. Diharapkan dengan diterapkannya model pembelajaran kooperatif akan membuat siswa menjadi lebih aktif, berpikir kritis, memupuk rasa kerjasama, dan tidak bosan. Dampaknya, terdapat pengaruh signifikan terhadap pemahaman konsep IPA dan motivasi belajar siswa.

Sesuai dengan pemaparan di atas, peneliti tertarik untuk melakukan penelitian mengenai model pembelajaran kooperatif tipe make a match. Huda (2012: 135) berpendapat bahwa model pembelajaran kooperatif tipe make a match membuat siswa mencari pasangan sambil mencari suatu konsep atau topik tertentu dalam suasana yang menyenangkan. Pada dasarnya model pembelajaran cooperative learning tipe 
make a match ini akan membuat suasana kelas menjadi hidup dan menyenangkan karena selain belajar siswa juga merasakan suasana bermain bersama teman lainnya.

Beberapa kelebihan make a match menurut Shoimin (2016) antara lain suasana kegembiraan akan tumbuh dalam proses pembelajaran, kerjasama antar-sesama siswa terwujud dengan dinamis, dan munculnya dinamika gotong-royong yang merata di seluruh siswa. Sedangkan kekurangan make a match menurut Shoimin (2016) adalah diperlukan bimbingan dari guru untuk melakukan pembelajaran, suasana kelas menjadi gaduh sehingga dapat mengganggu kelas lain, dan guru perlu persiapan bahan dan alat yang memadai.

Adanya beberapa perbedaan antara model pembelajaran explicit instruction dengan model pembelajaran kooperatif tipe Make a Match akan membuat perlakuan yang akan diterima oleh siswa juga berbeda. Artinya, diharapkan akan diperoleh perbedaan pemahaman konsep IPA yang signifikan antara model pembelajaran explicit instruction dengan model pembelajaran kooperatif tipe Make a Match. Selain itu, diharapkan dengan diterapkannya model pembelajaran yang berbeda akan berpengaruh secara signifikan terhadap motivasi belajar siswa.

Motivasi adalah dorongan yang terdapat dalam diri seseorang untuk berusaha mengadakan perubahan tingkah laku yang lebih baik dalam memenuhi kebutuhannya (Uno, 2016). Artinya, ada atau tidaknya perubahan tingkah laku seseorang bergantung pada kesadaran dan usaha orang itu sendiri untuk merubah tingkah lakunya. Selain itu, menurut Sardiman (2012) motivasi dapat dikatakan sebagai serangkaian usaha untuk menyediakan kondisi-kondisi tertentu, sehingga seseorang mau dan ingin melakukan sesuatu. Berdasarkan pada pemikiran tersebut, maka peneliti tertarik untuk melakukan penelitian tentang "PENGARUH MODEL PEMBELAJARAN COOPERATIVE LEARNING TIPE MAKE A MATCH TERHADAP PEMAHAMAN KONSEP IPA DITINJAU DARI MOTIVASI BELAJAR SISWA.

Tujuan penelitian ini adalah 1) untuk mengetahui perbedaan signifikan pemahaman konsep IPA antara siswa yang diajar menggunakan model pembelajaran cooperative learning tipe make a match dengan siswa yang diajar menggunakan model pembelajaran explicit instruction pada siswa Sekolah Dasar. 2) untuk mengetahui perbedaan signifikan pemahaman konsep IPA antara siswa yang memiliki motivasi belajar tinggi dan siswa yang memiliki motivasi belajar rendah pada siswa Sekolah Dasar.

\section{METODE}

Metode penelitian yang digunakan dalam penelitian ini adalah metode eksperimen semu (Quasi experimental research). Rancangan yang digunakan dalam penelitian ini adalah rancangan faktorial $2 \times 2$. Populasi dalam penelitian ini adalah siswa kelas V semester II SD Islam Se-Kecamatan Laweyan Tahun 2017/2018. Sampel yang digunakan pada penelitian ini adalah SDIT Ar-Risalah sebagai kelompok eksperimen dan SD Ta'mirul Islam sebagai kelompok kontrol. Penelitian ini menggunakan teknik pengumpulan data yang berupa tes dan nontes. Instrumen penilaian dalam penelitian ini menggunakan lembar tes pemahaman konsep IPA dan lembar angket motivasi belajar siswa.

Teknik pengambilan sampel yang digunakan dalam penelitian ini adalah Cluster Random Sampling. Teknik sampling ini digunakan untuk menentukan sampel yang berasal dari sumber data yang luas. Uji validitas yang digunakan dalam tes pemahaman konsep IPA adalah korelasi point biserial, sedangkan untuk angket motivasi belajar menggunakan korelasi product moment. Uji reliabilitas dalam tes pemahaman konsep IPA menggunakan KR-20, sedangkan untuk angket menggunakan alpha cronbach. Teknik analisis data penelitian ini menggunakan Analisis Variansi Dua Jalan. 


\section{HASIL DAN PEMBAHASAN}

Sebelum dilakukan uji analisis data, terlebih dahulu dilakukan uji prasyarat analisis. Uji prasyarat analisis mencakup uji normalitas dan uji homogenitas. Selain itu, digunakan uji-t untuk menguji keseimbangan kemampuan awal antara kelompok eksperimen dengan kelompok kontrol. Data yang digunakan dalam uji keseimbangan ini diambil dari nilai pre-test. Data rata-rata dan variansi data pre-test dapat dilihat pada tabel 1 berikut.

Tabel 1. Rata-rata dan Variansi Data Pre-test

\begin{tabular}{cccc}
\hline Kelompok & Jumlah Siswa & Rata-rata & s \\
\hline Eksperimen & 27 & 56,889 & 20,944 \\
Kontrol & 25 & 51,364 & 19,912 \\
\hline
\end{tabular}

Berdasarkan Tabel 1 diperoleh data kelompok eksperimen memperoleh rata-rata skor sebesar 56,889 dengan standar deviasi 20,994; sedangkan pada kelompok kontrol memperoleh rata-rata skor sebesar 51,364 dengan standar deviasi 19,912. Selanjutnya dilakukan uji normalitas data pre-test yang dapat dilihat pada tabel 2 berikut.

Tabel 2. Statistik Uji Normalitas Data Pre-test

\begin{tabular}{cccc}
\hline Sampel & Lmaks $_{\text {mabel }}$ & L $_{\text {tabel }}$ & Keputusan Uji \\
\hline Eksperimen & 0,1113 & 0,1665 & $\mathrm{H}_{0}$ diterima \\
Kontrol & 0,1403 & 0,1726 & $\mathrm{H}_{0}$ diterima \\
\hline
\end{tabular}

Berdasarkan Tabel 2 diperoleh harga Lnitung untuk setiap sampel tidak melebihi harga $L_{\text {tabel }}$ sehingga $\mathrm{H}_{0}$ diterima. Artinya sampel berasal dari populasi yang berdistribusi normal.

Hasil uji homogenitas menggunakan uji Bartlett dengan statistik uji Chi-kuadrat $\left(x^{2}\right)$ dan tingkat signifikansi 0,05 diperoleh nilai statistik uji $X^{2}$ hitung $=0,0635$ dan $x^{2}$ tabel adalah 3,841 dari kelompok eksperimen dan kelompok kontrol. Oleh sebab itu, keputusan uji menyatakan $\mathrm{H}_{0}$ diterima sebab $X^{2}$ hitung $<X^{2}$ tabel. Hal ini berarti kedua kelompok homogen.

Selanjutnya, dilakukan uji-t sebab telah diperoleh sampel penelitian yang berasal dari populasi yang berdistribusi normal dan variansinya homogen. Penelitian ini menggunakan jumlah siswa (n) yang berbeda dari masing-masing kelas. Apabila jumlah $(n)$ berbeda, maka rumus uji-t menggunakan rumus Polled Varians. Hasil dari uji keseimbangan dengan uji-t diperoleh thitung sebesar 0,9734. Sesuai dengan perhitungan, thitung $=0,9734 \notin \mathrm{DK}\{\mathrm{t} \mid \mathrm{t}<-1,6759$ atau $\mathrm{t}>1,6759\}$ atau $\mathrm{t}_{\text {hitung }}$ bukan anggota daerah kritis, maka Ho diterima. Oleh sebab itu, dapat ditarik kesimpulan bahwa kedua sampel penelitian mempunyai kemampuan awal yang sama atau kedua sampel penelitian tersebut dalam keadaan seimbang. Selanjutnya dilakukan uji normalitas data post-test yang diringkas pada tabel 3 berikut

Tabel 3. Ringkasan Uji Normalitas Post-test

\begin{tabular}{cccc}
\hline Sumber & $\mathbf{L}_{\text {makx }}$ & $\mathbf{L}_{\text {tabel }}$ & Keputisan Uji \\
\hline Kelompok Eksperimen & 0,0680 & 0,1665 & $\mathrm{H}_{0}$ diterima \\
Kelompok Kontrol & 0,1516 & 0,1726 & $\mathrm{H}_{0}$ diterima \\
Motivasi Belajar Tinggi & 0,1188 & 0,1641 & $\mathrm{H}_{0}$ diterima \\
Motivasi Belajar Rendah & 0,0853 & 0,1766 & $\mathrm{H}_{0}$ diterima \\
\hline
\end{tabular}

Berdasarkan tabel 3. yang menunjukkan bahwa harga $L=\operatorname{maks}\{|F(z i)-s(z i)|\}$ pada masing-masing kelompok eksperimen, kelompok kontrol, motivasi belajar tinggi dan motivasi belajar rendah tidak melebihi harga dari $L_{\text {tabel. }}$ Oleh sebab itu, keputusan uji menunjukkan bahwa $\mathrm{H}_{0}$ diterima. Artinya, sampel penelitian berasal dari populasi yang berdistribsi normal. Selanjutnya dilakukan uji homogenitas data post-test yang dapat dilihat pada tabel 4 berikut 
Tabel 4. Hasil Analisis Statistik Uji Homogenitas

\begin{tabular}{cccc}
\hline Sumber data & $\mathbf{x}^{2}$ hitung & $\mathbf{x}^{2}{ }_{\text {tabel }}$ & Keputusan Uji \\
\hline $\begin{array}{c}\text { Kelompok eksperimen } \\
\text { dan kontrol }\end{array}$ & 0,726 & 3,841 & $\mathrm{H}_{0}$ diterima \\
$\begin{array}{c}\text { Motivasi belajar tinggi } \\
\text { dan rendah }\end{array}$ & 0,214 & 3,841 & $\mathrm{H}_{0}$ diterima \\
$\quad$ Antar sel & 1,570 & 7,815 & $\mathrm{H}_{0}$ diterima \\
\hline
\end{tabular}

Berdasarkan tabel data hasil analisis uji homogentias pada tabel 4, nilai statistik uji homogenitas pada kelompok eksperimen dan kelompok kontrol, motivasi belajar tinggi dan rendah, serta antar sel tidak melebihi harga $X_{\text {tabel }}$ sehingga $\mathrm{H}_{0}$ diterima. Hal ini berarti data ketiga kelompok memiliki varians yang sama atau kelompok data homogen. Oleh sebab itu karena $x^{2}$ hitung $<X^{2}$ tabel maka keputusan uji menyatakan $\mathrm{H}_{0}$ diterima. Hal tersebut berarti kedua kelompok tersebut homogen.

Penelitian ini menggunakan analisis variansi dua jalan dengan sel tak sama pada tingkat signifikansi sebesar 0,05 untuk pengujian hipotesis. Hasil perhitungan analisis variansi dua jalan dengan sel tak sama terangkum pada Tabel 5 berikut:

Tabel 5. Hasil Analisis Variansi Dua Jalan Dengan Sel Tak Sama

\begin{tabular}{ccccccc}
\hline $\begin{array}{l}\text { Sumber } \\
\text { Varians }\end{array}$ & JK & DK & RJK & F hitung & $\mathbf{F}_{\text {tabel }}$ & $\begin{array}{c}\text { Keputusan } \\
\text { Uji }\end{array}$ \\
\hline Antar A & 1196,308 & 1 & 1196,308 & 5,2359 & 4,04 & $\mathrm{H}_{\text {OA ditolak }}$ \\
Antar B & 2741,912 & 1 & 2741,912 & 12,0007 & 4,04 & $\mathrm{H}_{0 \mathrm{~B}}$ ditolak \\
Dalam & 10967,036 & 48 & 228,47991 & - & - & - \\
Total & 13722,769 & 51 & - & - & - & - \\
\hline
\end{tabular}

Berdasarkan data tabel 5 menunjukkan bahwa; (1) terdapat perbedaan pemahaman konsep IPA antara siswa yang diajar dengan model pembelajaran cooperative learning tipe make a match dengan siswa yang diajar dengan model pembelajaran explicit instruction dengan nilai $F_{A}=5,2359>F_{\text {tabel }}=4.04$; (2) terdapat perbedaan pemahaman konsep IPA antara siswa yang memiliki motivasi belajar tinggi dengan siswa yang memeiliki motivasi belajar rendah dengan nilai $F_{B}=12,0007>F_{\text {tabel }}$ $=4.04$.

Berdasarkan hasil perhitungan Analisis Variansi Dua Jalan dengan sel tak sama koefisien $F_{A}$ dan $F_{B}$ menunjukkan adanya perbedaan yang signifikan. Dalam rangka mengetahui yang lebih baik antara satu dengan yang lainnya cukup dengan membandingkan besarnya rataan jumlah marginalnya. Rata-rata marginal skor masing-masing sel dapat dilihat pada tabel 6 berikut.

Tabel 6. Rata-rata Skor Masing-masing Sel

\begin{tabular}{cccc}
\hline \multirow{2}{*}{ Model Pembelajaran } & \multicolumn{2}{c}{ Motivasi Belajar } & \multirow{2}{*}{$\begin{array}{c}\text { Rata-rata } \\
\text { Marginal }\end{array}$} \\
\cline { 2 - 3 } & Tinggi $\left(\mathbf{B}_{1}\right)$ & Rendah $\left(\mathbf{B}_{2}\right)$ & \\
\hline $\begin{array}{c}\text { Cooperative Learning } \\
\text { tipe Make a Match }\left(\mathbf{A}_{1}\right)\end{array}$ & 69,067 & 66,667 & 67,867 \\
Explicit Instruction $\left(\mathbf{A}_{2}\right)$ & 67,692 & 66,333 & 67,013 \\
Rata-rata Marginal & 68,3795 & 66,5 & \\
\hline
\end{tabular}

Berdasarkan tabel 6 diatas dapat diketahui bahwa diperoleh rataan marginal baris $\left(A_{1}\right)$ sebesar 67,867 . Pada rataan marginal dari baris $\left(A_{2}\right)$ diperoleh hasil sebesar 67,013 . Rataan marginal kolom $\left(B_{1}\right)$ diperoleh hasil sebesar 68,3795 dan rataan marginal kolom $\left(\mathrm{B}_{2}\right)$ diperoleh hasil sebesar 66,5. 
Hipotesis pertama $\left(\mathrm{H}_{\mathrm{OA}}\right)$ ditolak, artinya ada perbedaan pemahaman konsep IPA antara siswa yang diajar dengan menggunakan model pembelajaran cooperative learning tipe make a match dengan siswa yang diajar dengan menggunakan model pembelajaran explicit instruction. Hipotesis kedua $\left(\mathrm{H}_{\mathrm{OB}}\right)$ ditolak, artinya ada perbedaan pemahaman konsep IPA antara siswa yang memiliki motivasi belajar tinggi dengan siswa yang memiliki motivasi belajar rendah.

\section{SIMPULAN}

Kesimpulan yang dapat ditarik pada penelitian ini antara lain: (1) Ada perbedaan pemahaman konsep IPA antara siswa yang diajar dengan menggunakan model pembelajaran cooperative learning tipe make a match dengan siswa yang diajar dengan menggunakan model pembelajaran explicit instruction; (2) Ada perbedaan pemahaman konsep IPA antara siswa yang memiliki motivasi belajar tinggi dengan siswa yang memiliki motivasi belajar rendah.

Hasil penelitian ini memperkuat teori yang mendasari bahwa model pembelajaran cooperative learning tipe make a match merupakan pembelajaran yang membuat siswa mencari pasangan sambil mencari suatu konsep atau topik tertentu dalam suasana yang menyenangkan (Huda, 2012). Berdasarkan kaitan ini, model pembelajaran cooperative learning tipe make a match memberikan pengaruh yang lebih baik terhadap pemahaman konsep khususnya pada mata pelajaran IPA.

Penelitian ini memperkuat teori yang mendasari bahwa motivasi adalah dorongan yang terdapat dalam diri seseorang untuk berusaha mengadakan perubahan tingkah laku yang lebih baik dalam memenuhi kebutuhannya (Uno, 2016). Hal ini menunjukkan bahwa motivasi belajar berpengaruh dalam memenuhi kebutuhan hasil belajar siswa. Hasil penelitian ini menunjukkan pentingnya penerapan model pembelajaran inovatif dan bervariasi, salah satunya adalah model pembelajaran cooperative learning tipe make a match.

Berdasarkan simpulan diatas, dapat dijadikan rekomendasi bagi para pendidik untuk menerapkan model pembelajaran cooperative learning tipe make a match dalam rangka mempengaruhi pemahaman konsep IPA dan motivasi belajar siswa menjadi lebih baik.

\section{DAFTAR PUSTAKA}

Huda, M. (2012). Cooperative Learning Metode, Teknik, Struktur, dan Metode Penerapan. Yogyakarta: Pustaka Pelajar.

Huda, M. (2014). Model-model Pengajaran dan Pembelajaran. Yogyakarta: Pustaka Pelajar.

Santoso, S. (2013). Pengaruh Model Pembelajaran Kolaboratif dan Motivasi Belajar Terhadap Peningkatan Hasil Belajar Fisika Siswa Kelas X SMA Negeri 1 Purwantoro Wonogiri, Jawa Tengah.Berkala Fisika Indonesia, Vol 5 No 1, 1819.

Sardiman. (2012). Interaksi \& Motivasi Belajar Mengajar. Jakarta: PT Raja Grafindo Persada.

Shoimin, Aris. (2016). 68 Model Pembelajaran Inovatif dalam Kurikulum 2013. Yogyakarta: Ar-Ruzz Media.

Susanto, A. (2013). Teori Belajar dan Pembelajaran di Sekolah Dasar. Jakarta: Kencana Prenada Media Group.

Trianto. (2013). Mendesain Model Pembelajaran Inovatif, Progresif, Konsep, Landasan, dan Implementasinya Pada Kurikulum Tingkat Satuan Pendidikan (KTSP). Jakarta: Kencana Prenada Media Group.

Uno, H. B. (2016). Teori Motivasi dan Pengukurannya Analisis di Bidang Pendidikan. Jakarta: Bumi Aksara.

Wisudawati, A. W \& Eka S. (2014). Metodologi Pembelajaran IPA. Jakarta: Bumi Aksara. 